\title{
Petko Hristov
}

petko.hristov@iefem.bas.bg

Instytut Etnologii i Studiów Folklorystycznych

Muzeum Etnograficzne

Bułgarska Akademia Nauk

\section{Serbowie: nasi najbliżsi pobratymcy czy podstępni wrogowie? Obraz Serbów w bułgarskiej prasie z końca lat dziewięćdziesiątych XX wieku ${ }^{1}$}

\section{Serbs: Our Closest Brothers or Our Most Treacherous Enemies? The Image of Serbs in Bulgarian Press of the late 1990s}

\begin{abstract}
Streszczenie: Od czasu powstania nowoczesnego państwa bułgarskiego w drugiej połowie XIX wieku stosunek bułgarskich intelektualistów, pisarzy, historyków i naukowców do Serbów był wysoce niejednoznaczny. Ekstrema wahań między serbofobią a serbofilią, często idących w parze z zawirowaniami polityki słowianofilskiej na Bałkanach, sięgały od głębokiej wzgardy do nieopanowanej sympatii. Okresy ocieplenia w stosunkach politycznych przeplatały się z okrutnymi, bratobójczymi wojnami. To wymusiło na autorach publikujących w bułgarskiej prasie, często w celach propagandowych, przyjęcie zestawu stosownych stereotypów. Wiele z nich powróciło w latach dziewięćdziesiątych XX wieku, dekadzie naznaczonej krwawym rozpadem byłej Jugosławii. W artykule autor przedstawia niektóre z nich, opierając się na artykułach, które ukazały się w opiniotwórczych mediach.
\end{abstract}

Slowa kluczowe: Serbowie, bułgarska prasa, serbofobia, serbofilia, stereotyp

Tłumaczenie: Klaudyna Michałowicz

Summary: In the article are presented the ambiguous attitudes of Bulgarian intellectuals, writers, historians and scholars in the modern age - after the formation of the contemporary Bulgarian state in the second half of the $19^{\text {th }}$ century. Fluctuations between Serbophobia and Serbophilia, often following the twists of Slavophilic politics on the Balkans, vary between complete disregard and unreserved sympathy. Different periods of warm political relations and of cruel "fratricidal" wars took turns in history and imposed a number of clichés in Bulgarian publications, often used for propaganda purposes. The decade of the 1990s, marked by the bloody break up of former Yugoslavia, revived a number of these clichés. The author presents some of them in the article, based on publications in mainstream media.

Key words: Serbs, Bulgarian publications, Serbophobia, Serbophilia, cliché

Translated by Author

\footnotetext{
${ }^{1}$ Tekst z języka angielskiego przetłumaczyła Klaudyna Michałowicz.
} 
Baj Ganiu, najsłynniejszy bohater literacki stworzony pod koniec XIX wieku przez znakomitego bułgarskiego pisarza Aleko Konstantinova, wjeżdżając pociągiem do Serbii wołał znacząco: „Już ja ich znam!” pod adresem całej serbskiej nacji, a na dworcach w Niszu i Belgradzie prowokował pracowników kolejowych i tragarzy, pytając wszystkich po kolei: „A ty nie jesteś Bułgarem? Przyznaj się. Wy wszyscy jesteście Bułgarami, tylko udajecie Serbów" (Konstantinov 1985: 25)². Przykład ten ilustruje, jak powszechne były postawy nieufności i lekceważenia wobec Serbów w młodym państwie bułgarskim, które w tym okresie dopiero wypracowywało swą nowoczesną tożsamość i żarliwie głosiło nowo nabyte ideały narodowe. Jednakże w Do Chicago i z powrotem, reportażu z podróży do Stanów Zjednoczonych, ten sam Konstantinov z sympatią relacjonuje miłe spotkanie z obywatelem Serbii, niejakim Nedkoviciem, które miało miejsce podczas Wystawy Kolumbijskiej w Chicago w 1893 roku. Panowie usiedli w barze i w trakcie pogawędki, „ku wielkiej uciesze amerykańskiej klienteli baru” (Konstantinov 2005: 35), odśpiewali pieśń Hristos Voskrese w języku starosłowiańskim.

Więź historyczno-kulturowa, jaka przez stulecia łączyła Bułgarów i Serbów, jest silniejsza niż niemal wszystkie podobne związki między narodami w skali całego świata (zob. Pantev 1999: 9). Od czasów wypraw wojennych chana Presjana w IX wieku, te dwie nacje siedem razy stawały do wojny przeciwko sobie, czterokrotnie w średniowieczu i trzykrotnie w czasach nowożytnych. Tego rodzaju wspólne losy wyryły głębokie ślady w ich pamięci historycznej. Jednakże tak u Bułgarów, jak i u Serbów pamięć ta jest osobliwie wybiórcza. Dla przykładu, w 1885 roku Bułgarzy agresywnie demonstrowali radość ze zwycięstwa nad ,serbską obłudą”, mimo że oba narody stały w obliczu wspólnego wroga - Imperium Osmańskiego. Nawet dzisiaj nikt w Bułgarii nie zada sobie trudu, by zrozumieć, z jaką niechęcią Serbowie odnosili się do tej wojny. Później zaś nikt w Serbii nie podjął wysiłku, by zrozumieć prawdziwe przyczyny ataku armii bułgarskiej w 1913 roku, który rozpoczął drugą wojnę bałkańską, znaną również jako „wojna sprzymierzeńców”. Był to akt politycznego szaleństwa, za które Bułgarzy zapłacili bolesną porażką próby zjednoczenia narodowego. W 1903 roku pannę Durham zaszokowała radość Serbów po upadku powstania ilindeńskiego, które rewolucjoniści określający się jako Bułgarzy zorganizowali w Macedonii. Z kolei wiele lat później Ilia Erenburg gorszył się entuzjastyczną reakcją Sofii na bombardowanie Belgradu przez Niemców, po którym duża część miasta legła w gruzach (Pantev 1999: 9).

\footnotetext{
${ }^{2}$ Aleko Konstantinov (1863-1897) - jeden z najlepszych nowożytnych satyryków bułgarskich; tworzył w ostatnich dekadach XIX w. Jego najsłynniejsze dzieło to powieść Baj Ganiu, w której Konstantinov wyśmiewa ubóstwo duchowe, agresywność i nieuzasadnione pretensje bogacącego się parweniusza. W książce Do Chicago i z powrotem opisana jest jego wizyta w Chicago podczas Światowej Wystawy Kolumbijskiej w 1893 r. Dzieła Konstantinova są do dzisiaj lekturą obowiązkową w bułgarskich szkołach.
} 
Petyr Mutafchiev, znany bułgarski historyk, tuż przed wybuchem drugiej wojny światowej w następujący sposób podsumował „katastrofę narodową” Bułgarii po konferencji pokojowej w Paryżu w 1919 roku:

(...) w mroku swoich błahych istnień, wśród niezliczonych przeciwności (Serbowie - przyp. P.H.) przygotowywali się na wielką chwilę, w której miały się rozstrzygnąć losy wszystkich narodów. A gdy chwila ta nadeszła, to oni, ci słabi i pogardzani, których my, Bułgarzy, zwykliśmy postrzegać jako ludzi bezwartościowych, okazali się nie tylko bardziej żywotni, lecz także o wiele mądrzejsi od nas, którzy karmiliśmy się iluzją potęgi i wyższości (Mutafchiev 1987: 154)³.

Wiele lat później znajdziemy swego rodzaju „odpowiedź”, gest lekceważenia ze strony serbskiej. Jest to fragment komentarza zatytułowanego „Mi, Bugari, ostali” (My, Bułgarzy, ci inni) w belgradzkiej gazecie „Blic” z 2011 roku:

\begin{abstract}
Nie wiemy nic o historii Bułgarii, ale żywimy przekonanie, że Bułgarzy są głupi, prymitywni i barbarzyńscy. Żaden z naszych narodów nie powinien mieć złudzeń co do drugiego. Powiedzcie jakiemuś Serbowi, że w średniowieczu państwo bułgarskie odgrywało na Bałkanach większą rolę niż Serbia, a natychmiast uzna wasze stwierdzenie za akt zdrady narodowej, chociaż jest to (nie) mily fakt (Blic, 9 stycznia 2011).
\end{abstract}

W perspektywie geograficznej Serbia i Bułgaria to dzisiaj główne państwa Bałkanów. Tworzą one kręgosłup półwyspu, o którym wciąż najczęściej mówi się „beczka prochu”. Naturalne jest zatem, że należy postawić pytanie: czy da się ustabilizować stosunki między nimi, biorąc pod uwagę to, jak bardzo są one nienormalne? Jako historyk i etnolog odpowiadam: dopóki rozsądek będzie ustępował emocjom wzbudzanym przez zaszłości historyczne, dopóty losy Bałkanów będą się rozstrzygać poza Bałkanami.

W tradycyjnym folklorze bułgarskim nie pojawia się postać Serba. Grupy określane jako „obcy”, to Turcy (także w wersji „bośniaccy Turcy”), Grecy, Wołosi, Żydzi, a nawet „łacinnicy” (co oznacza katolików) - ale nie Serbowie. W bułgarskich eposach heroicznych tradycyjnym wrogiem bohatera jest Turek, a oszustem Grek, niekiedy Żyd. Serbowie zaczęli się pojawiać dopiero po wojnie serbsko-bułgarskiej w 1885 roku, i to w kontekście miejskim - w piosenkach wykonywanych na targach i jarmarkach przez wędrownych muzykantów oraz w publikowanych śpiewnikach. Wcześniej, także w okresie odrodzenia narodowego, ideolodzy bułgarskiego ruchu narodowowyzwoleńczego widzieli w Serbach sprzymierzeńców i bliskich krewnych pod względem pochodzenia, języka i religii, na których pomocy mogli polegać przy organizowaniu oporu przeciwko rządom osmańskim. To Belgrad udzielał schronienia najsłynniejszym bułgarskim rewolucjonistom; to właśnie

\footnotetext{
${ }^{3}$ Kniga za Bulgarite wybitnego bułgarskiego historyka Petyra Mutafchieva ukazała się drukiem w 1987 r.; dzieło oparte jest na rękopisie monografii, która po śmierci autora w 1943 r. nie została opublikowana.
} 
w Belgradzie w 1862 roku Georgi Rakowski organizował, na wzór Garibaldiego, Pierwszy Legion Bułgarski, który miał wyzwolić kraj spod władzy osmańskiej. Podczas niezliczonych wojen serbsko-tureckich, to do serbskiej armii zaciągało się tysiące bułgarskich ochotników w nadziei, że zdołają wreszcie wyzwolić Bułgarię spod władzy sułtanów. Później jednakże stało się jasne, że serbscy politycy, kierując się wskazówkami zawartymi w Szkicu (Načertanije) Ilji Garašanina, chcą wykorzystać bułgarski ruch narodowowyzwoleńczy w celu rozszerzenia terytorium Serbii na południe i wschód, co w efekcie spowodowałoby zajęcie przez Serbię ziem bułgarskich. Wtedy „braterskie” więzi zostały zerwane; Legion Bułgarski przeniósł się na Wołoszczyznę, a wraz z nim większość rewolucjonistów.

Mimo tego większość Bułgarów nadal postrzegała Serbów jako „współ-Słowian i braci w wierze prawosławnej", najbliższych im spośród wszystkich narodów bałkańskich. Nie przypadkiem Serbia była pierwszym państwem, jakie po wyzwoleniu Bułgarii w 1878 roku przysłało do Sofii swojego ambasadora i to pomimo tego, że Bułgaria była wciąż podległa władzy sułtańskiej (Hristov 2003: 113). Nagły zwrot we wzajemnych stosunkach nastąpił w 1885 roku, kiedy Milan - król Serbii, po zjednoczeniu Księstwa Bułgarii oraz Wschodniej Rumelii, zaatakował młode państwo bułgarskie. Jak stwierdził Konstantin Jireček w odniesieniu do środkowo-zachodniej części Bułgarii: „Nawet jeśli po okresie serbskiej okupacji (lata 1878-1879, gdy władza w regionie należała do Serbów - przyp. P.H.) pojawiły się jakieś pro-serbskie sympatie, zanikły one całkowicie po wojnie serbsko-bułgarskiej w 1885 roku" (Jireček 1899: 501).

Po klęsce armii serbskiej w bitwie pod Sliwnicą ${ }^{4}$ w 1885 roku, król Milan pozostał w folklorze bułgarskim jako ten ,podstępny brat”, który „,wbił nóż w plecy” stacjonującej w Tracji bułgarskiej armii przygotowywanej na atak ze strony osmańskiej. Ten „Judasz Iskariota”, „zawistny Kain” oraz „król bratobójca” „zamordował dwa bratnie narody” oraz „rozlał krew pobratymczą”. Za jego sprawą ,poróżnili się dwaj bracia, Serbowie i Bułgarzy przystąpili do wojny”. To właśnie wtedy w mentalności bułgarskiej po raz pierwszy pojawił się związany z osobą „króla bratobójcy” obraz „szumadzkiej świni” („królu Milanie, ty szumadzka świnio”), a następnie wykształcił się bardziej ogólny ogląd sąsiedzkiego narodu: „Te świnie Serbowie zaczęli z nami wojnę, nie wiedząc, że to grzech!". Tego rodzaju motywy weszły do folkloru piosenki miejskiej i na długie lata naznaczyły wizerunek Serba w oczach bułgarskiego społeczeństwa. Jako kolejny przykład, dowodzący fałszywej natury Serbów, przytaczano brak uznania dla

\footnotetext{
${ }^{4}$ Bitwa ta, która rozegrała się w 1885 r. pod miasteczkiem Sliwnica niedaleko Sofii, stolicy Bułgarii, miała kluczowe znaczenie dla przebiegu wojny serbsko-bułgarskiej. Po klęsce serbska armia musiała wycofać się na terytorium Serbii i jedynie interwencja Austro-Węgier ocaliła Królestwo Serbii od ostatecznej porażki.
} 
bułgarskich ochotników, którzy wspomogli ich podczas serbsko-tureckich wojen narodowowyzwoleńczych: „Na piersiach naszych nie widzą medali, które za naszą dzielność sami nam dali!" (por. Anchev 1995: 137)5.

Podczas wojen bałkańskich oraz pierwszej wojny światowej taki obraz Serbii i Serbów będzie powielany w prasie, szczególnie w karykaturach autorstwa znanych bułgarskich artystów, członków grupy Balkanski Papagal (Bałkańska Papuga). W latach 1915-1916 zdechłą „szumadzką świnię” przedstawiano jako wiszącą na choince ozdobę lub nadziane na rożen prosię serwowane w europejskim cyrku (Gehl, Petrov 2005: 152-189). Jednak później, po podpisaniu w 1919 roku traktatu w Neuilly, na mocy którego większość Macedonii oraz zamieszkane przez Bułgarów tzw. zachodnie pogranicze przejęło nowo utworzone Królestwo Serbów, Chorwatów i Słoweńców, Serbię uosabiał już kat odziany w mundur szumadzkiego żołnierza lub lew odrywający Macedonię od Bułgarii.

Po włączeniu terytoriów przygranicznych do Królestwa Serbów, Chorwatów i Słoweńców w 1919 roku, w zbiorowej wyobraźni Bułgarów rejon Bosilegradu oraz okolice między Caribrodem a Tranem stały się uosobieniem utraconego i gorzko opłakiwanego „zachodniego pogranicza”. Wcześniej tą część Bułgarii z zasady opisywano jako zacofaną, prymitywną, ciasną i skostniałą. Po 1919 roku nastąpiła heroizacja „oderwanych od Macierzy dziatek Zachodniej Bułgarii” (Hristov 2002: 75). Bułgarska propaganda straciła wszelki umiar w używaniu epitetów i przenośni. Podobieństwo dialektu i obyczajów tamtejszych Bułgarów, mieszkańców okolic miasta Pirot oraz, ogólniej, wschodniej Serbii przestało być postrzegane jako wartość pozytywna. Zaczęto je prezentować jako zagrożenie wymagające „obudzenia czujności narodowej”. Oto wskazówki, jakie ukazały się w drukowanej w Sofii gazecie „Echo Zachodnie”, przeznaczonej dla uchodźców z ,zachodniego pogranicza”:

\footnotetext{
Wasi pogromcy (tj. Serbowie - przyp. P.H.) są zdolni i w swej dwulicowości gotowi przekonywać was i namawiać, a jednocześnie razić swymi grotami filary narodu, mierzyć w narodowego ducha; bądźcie więc czujni i w najwyższym stopniu ostrożni. Pokrewieństwo naszych języków oraz podobieństwo wiary i obyczajów ułatwiają im zadanie, więc trzeba uważać (Echo Zachodnie, 15 lutego 1923: 1).
}

Nagłówek w tej samej gazecie, w numerze z 17 kwietnia 1923 roku nawołuje: „Nie próbujcie mówić po serbsku!" (Echo Zachodnie, 17 kwietnia 1923: 1). Na jej łamach opisywano różne sposoby walki z serbską polityką asymilacyjną, np. z obowiązkowymi apelami szkolnymi (slava), które odbywały się w dniu św. Sawy zamiast w obchodzony oficjalnie w bułgarskich szkołach dzień św. św. Cyryla i Metodego (Hristov 2002: 76).

\footnotetext{
${ }^{5}$ Zbiór pieśni o wojnie serbsko-tureckiej.
} 
Najbardziej negatywny był wizerunek ,serbskich okupantów Macedonii”. W nowo utworzonej prowincji Vardar Banovina, Wewnętrzna Macedońska Organizacja Rewolucyjna (VMRO), która powstała w 1893 roku w Salonikach i miała na celu wyzwolenie Macedonii spod władzy osmańskiej, rozpoczęła zajadłą kampanię terroru oraz partyzantkę przeciwko serbskim władzom. Zawołanie: „Srbe - na vrbe!” (dosłownie: „Serbów na wierzby!"), wymyślone przez Słoweńca Marko Natlačena i spopularyzowane przez jego wiersz Wieszać Serbów (1914), przejęli nie tylko chorwaccy ustasze w latach czterdziestych, lecz także członkowie VMRO w wersji bułgarskiej: „Sărbite - na varbite!”.

Jak widać, od połowy XIX wieku aż do natowskich bombardowań w 1999 roku stosunki między Bułgarią a Serbią / Jugosławią co chwila się zmieniały. Nieustannie oscylowały między ekstremami filii i fobii, między przyjaźnią a rywalizacją, nierzadko przechodząc od serdecznych związków do ostrych konfrontacji. Liczne deklaracje braterskiej miłości składane przez polityków po obu stronach (często z błogosławieństwem słowianofilskiej Rosji) głuszyła strzelanina - najpierw podczas wojny serbsko-bułgarskiej w 1885 roku, następnie podczas wojen bałkańskich i pierwszej wojny światowej, a jeszcze później podczas drugiej wojny światowej, w czasie okupacji wschodniej Serbii przez Bułgarię, kiedy obecność bułgarskich wojsk okupacyjnych umocniła tradycyjny wśród Serbów pogląd, że Bułgarzy to tacy sąsiedzi, co „zawsze wbiją nam nóż w plecy”.

Współpraca bułgarskiej i jugosłowiańskiej partyzantki antyfaszystowskiej doprowadziła do podpisania w 1947 roku układu o przyjaźni, współpracy i wzajemnej pomocy. W zamyśle miał on przetrzeć szlak w kierunku powstania federacji Bułgarii i rządzonej przez Josipa Broz Tito Jugosławii. Przyjaźń między marszałkiem Tito a Georgim Dimitrowem skończyła się jednakże w 1948 roku z chwilą, gdy biuro Kominformu podjęło uchwałę o wykluczeniu Jugosławii. Tym samym stała się ona „państwem rewizjonistycznym” oraz wrogiem Związku Radzieckiego i innych państw demokracji ludowej. Nieprzypadkowo za czasów Todora Żiwkowa w Bułgarii mówiło się o „bratniej Algierii”, ale „sąsiedniej Jugosławii” (Pantev 1999: 9). W Jugosławii pod rządami marszałka Tito aparat ideologiczny rozdymał obawę przed zewnętrznym wrogiem, a „strach przed sąsiadami był lepiszczem dla kraju, który wcześniej czy później musiał rozlecieć się na kawałki” (Stefanov 1999: 11, 14). W Bułgarii natomiast reżim Żiwkowa wprowadził całkowitą blokadę informacji dotyczących wszelkich wydarzeń za zachodnią granicą kraju. W warunkach narzuconej odgórnie blokady informacyjnej Jugosławia stała się dla Bułgarów symbolem Zachodu - ,ich czałga $a^{6}$, kultura piwiarniana i rozrywki były obiektem zazdrości” (Aleksandrov 1999: 8).

\footnotetext{
${ }^{6}$ Gatunek muzyki popularnej.
} 
Wczesne lata dziewięćdziesiąte XX wieku są początkiem demokratycznych zmian w Bułgarii, a jednocześnie okresem gwałtownego rozpadu Jugosławii. Wydarzenia te wystawiły na ciężką próbę wszelkie przekonania, jakie Bułgarzy żywili na temat Serbów i Serbii (Todorov 2000). Wtedy też wróciło wiele stereotypów znanych z przeszłości. Trudno uznać, aby okres ten sprzyjał wytworzeniu się „normalnego” wizerunku Serbów, skoro głównym czynnikiem, który wpłynął na jego kształt, były konflikty zbrojne. Wydobyły one z mroków historii stary pogląd, że Serbowie to aroganccy ultranacjonaliści oraz waleczny i uparty „,naród żołnierzy”, ale nie postawiły Serbów w roli ofiary. Sporadyczne próby oddzielenia wizerunku Serbów od wizerunku państwa serbskiego okazały się bezowocne, wobec czego Serbowie nadal postrzegani są w sposób „wygodny”, czyli zbiorowo.

Negatywny obraz serbskiego nacjonalizmu został ujęty w dwóch deklaracjach: podpisanym w listopadzie 1991 roku liście osiemdziesięciu dziewięciu bułgarskich pisarzy „do rządów państw członkowskich Organizacji Narodów Zjednoczonych oraz do polityków i intelektualistów całego świata” w sprawie „,agresji Jugosławii wobec Republiki Chorwackiej”, a także w podpisanej w kwietniu 1999 roku Deklaracji intelektualistów butgarskich $w$ sprawie wojny w Jugosławii. W tej ostatniej powtarza się stwierdzenie:

Zaczepny totalitaryzm rządzących Serbią socjalistów pozostaje niezwyciężony, ponieważ idealnie łączy agresywność komunistycznego faszyzmu z potwornościami nacjonalistycznej demagogii (...). Społeczność międzynarodowa musi jak najszybciej potępić ludobójstwo, jakiego dopuszczają się serbscy szowiniści (...). Czerwony faszyzm musi zostać powstrzymany! (Deklaracja intelektualistów bułgarskich w sprawie wojny w Jugosławii).

Podjęta w 1999 roku, przez kolejną grupę stu lewicujących intelektualistów, próba poparcia idącego z Aten apelu „O pokój na Bałkanach!” oraz o zaprzestanie bombardowania ,resztek” Jugosławii przez NATO, została wythumiona przez media. Słynny bułgarski poeta i uczony Waleri Petrov skonstatował wówczas ze smutkiem:

Jeśli pozwolimy się uwikłać w napaść na Jugosławię, będzie to już drugi raz, jak wbijemy naszym
sąsiadom nóż w plecy; na Bałkanach otworzą się wówczas nowe przepaści (...) o wiele głębsze niż
te z przeszłości, które przecież nie przyniosły nam nic prócz cierpień (OMDA. Wonderland Bulgaria).

W społeczeństwie bułgarskim ukształtował się pogląd, że Serbowie wiecznie muszą być z kimś w konflikcie: z muzułmanami, Chorwatami, Czarnogórcami, Unią Europejską, Stanami Zjednoczonymi, NATO, Albanią, Bułgarią itd. Jeśli można tu mówić o tendencji, to polegałaby ona głównie na trwałości paradoksalnego faktu, że wciąż nie istnieje neutralny wizerunek Serba. Serbowie są albo źli, albo dobrzy, w zależności od tego, która z dwóch interpretacji w świetle geopolityki, ideologii oraz psychologii społecznej uznawana jest za obowiązującą. Przy budowaniu wizerunku Serbów zachowane zostały 
opozycje: islam - słowiańszczyzna oraz polityczna lewica - prawica jako „ci dobrzy” i „ci źli”, czyli „bracia, którzy zawsze wbiją nam nóż w plecy”. Wyjątkowa trwałość i niezmienność tego obrazu na przestrzeni dekad jest zdumiewająca. Jak stwierdził historyk Andrei Pantev, „Na Bałkanach nie ma bratnich krajów. Różnice między krajami bałkańskimi manifestują się ostro nawet wtedy, gdy są komicznie wręcz drobne i całkiem bez znaczenia" (Pantev 1999: 12).

Na zakończenie pragnę przypomnieć słowa nieżyjącego już profesora Milczo Lalkova, który wiele mnie nauczył o historii Bałkanów:

\begin{abstract}
Mamy fatalną teraźniejszość i niepewną przyszłość; szukamy więc pociechy w przeszłości. A tam zderzamy się z naszymi sąsiadami, bo oni też kiedyś byli wielcy. My tutaj, na Bałkanach, w prawdziwie Ezopowym stylu bez końca powtarzamy tę bajkę, w której wilk spotyka jagnię i mówi: „Tyś mi nic nie zrobiło, ale twój ojciec i owszem, a więc na tobie się zemszczę". Żaden z naszych narodów nie chce zaakceptować tego drugiego jako równego sobie; korzystamy więc z historii jako narzędzia zemsty za dawne klęski i zastarzałe rany. Kiedy nasi sąsiedzi nas prześcigają, patrzymy na nich z zazdrością i nienawiścią. Kiedy my prześcigamy ich, patrzymy na nich z pogardą. Każdy z nas sądzi, że ma wiele do wzięcia z historii - kosztem swoich sąsiadów, a nic nie musi oddawać (Lalkov 2000: 9).
\end{abstract}

Mam ogromną nadzieję, że w przyszłości to się zmieni. Abyśmy nie szli już więcej w ślady baja Ganiu i przestali wołać z pogardą: „Już ja ich znam!” pod adresem Serbów.

\title{
Bibliografia
}

Anchev, A. (1995). Pesni Zasrŭbsko-bŭlgarskata voyna ot 1885 g. Sofia: May.

Hristov, P. (2003). Nikola Pashich and His Work in Emigration in Bulgaria. Razvitak, 213/214, 113-120.

Hristov, P. (2002). Use of the Holiday for Propaganda Purposes (the "Serbian" slava and/ or the "Bulgarian" sabor). Ethnologia Balkanica, 6, 69-80.

Echo Zachodnie, 15. II.; 17. IV. 1923.

Gehl, K., Petrov, P. (2005). Die Nachbarn Bulgariens im Spiegel der Karikaturen ”Balkanski papagal” (1915-1927). Zeitschrift für Balkanologie, 41, 152-189.

Jireček, K. (1899). Pŭtuvaniya iz Bŭlgariya. Sofia.

Konstantinov, A. (1986). Baj Ganiu (przeł. F. Korwin-Szymanowski). Warszawa: Czytelnik.

Konstantinov, A. (2005). Do Chikago i nazad. Sofia: IK „PAN'96”.

Lalkov, M. (2000). 24 Chasa, 3. III., 9.

Mutafchiev, P. (1897). Kniga za Bŭlgarite. Sofia: BAN. 
Pantev, A. (1999). Mrazim se kato bratya. 24 Chasa, 1. IV., 9.

Stefanov, L. (1999). 24 Chasa, 2. X., 11-14.

Todorov, M. (2000). „Znam gi az tyakh!” Sŭrbiya i sŭrbite v bŭlgarskata literatura. Sofia: Liter Net.

\section{Źródła internetowe}

Blic http://www.blic.rs/komentar/mi-bugari-ostali/8cfppgb

Deklaracja intelektualistów bułgarskich w sprawie wojny w Jugosławii (1990) http://www.kultura.bg/media/my_html/2078/c_mih.htm

OMDA. Wonderland Bulgaria http://www.omda.bg/index.php?IDMenu=1\&IDLang=1 
